\title{
Relationship between Breastfeeding and Malocclusion: A Systematic Review of the Literature
}

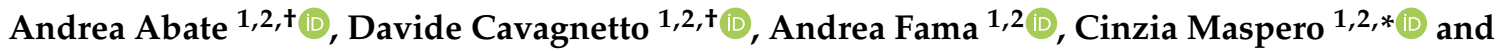 \\ Giampietro Farronato ${ }^{1,2}$ \\ 1 Department of Biomedical, Surgical and Dental Sciences, School of Dentistry, University of Milan, \\ 20100 Milan, Italy; andreabate93@gmail.com (A.A.); davide.cavagnetto@gmail.com (D.C.); \\ andreas.fama@hotmail.it (A.F.); giampietro.farronato@unimi.it (G.F.) \\ 2 Fondazione IRCCS Cà Granda, Ospedale Maggiore Policlinico, 20100 Milan, Italy \\ * Correspondence: cinzia.maspero@gmail.com; Tel.: +39-338-334-4999 \\ + These authors contributed equally to this work.
}

Received: 6 October 2020; Accepted: 27 November 2020; Published: 30 November 2020

\begin{abstract}
Background: The purpose of this systematic review was to analyze the available literature about the influence of breastfeeding in primary and mixed dentition on different types of malocclusions. Methods: Preferred Reporting Items for Systematic Reviews and Meta-Analyses Protocols (PRISMA-P) guidelines were used to perform the present review. The following electronic databases were searched: Pubmed, Evidence-Based Medicine Reviews (EBMR), Embase, Cochrane Library, Medline, Web of Science and Ovid. Results: A primary research found a total of 279 articles. Two more papers were also considered from the gray literature. Two hundred sixty-three articles were excluded as they were deemed irrelevant on the basis of: duplicates, title, abstract, methods and/or irrelevant contents. Eighteen papers were selected and included in the qualitative analysis. Conclusions: breastfeeding is a positive factor that seems to reduce the incidence of posterior crossbite, skeletal class II and distoclusion in primary and mixed dentition. A sort of positive relationship between months of breastfeeding and risk reduction seems to exist. More longitudinal research is needed to avoid bias in the results, with data collected prospectively on the months of exclusive breastfeeding, by means of specific questionnaires and successive clinical evaluation of the occlusal condition at the primary dentition, mixed dentition and permanent dentition stages.
\end{abstract}

Keywords: malocclusion; cross-bite; breastfeeding; orthodontics

\section{Introduction}

The stomatognathic system is composed of static and dynamic structures and its harmonious functioning is based on the balanced relationship between them. The functions that include the stomatognathic apparatus (sucking, respiration, speech, chewing, swallowing) are believed to be the factors that most influence the model of maxillofacial development and the position of the teeth in the child's arch [1-4]. The genesis of a malocclusion is usually linked to an impairment of some kind to eugnathic growth that involves to various extents the mandible, the maxilla [5], and the functional matrix (tongue and facial muscles). Exclusive breastfeeding between 0 and 6 months is recommended by the World health Organization (WHO) as a public health policy because it reduces the risk of aerodigestive infections [6-8]. Moreover, breastfeeding is one of the cornerstones of a correct maxillofacial growth because it promotes proper lip seal, mandibular function and tongue correct position against the palate [9]. Breastfeeding forces the child to actively squeeze milk out of the mother's breast through a synergic action of both tongue and facial muscles, whereas bottle-feeding requires less effort to drain the milk, thus under stimulating the functional matrix [10-13]. 
The suction reflex is the first coordinated muscular activity performed by the newborn.

In the literature there are two forms of suction described: nutritive (breastfeeding and bottle-feeding) and non-nutritive suction [14-16]. The first one provides the child with the essential nutrients for their optimal development and growth; in particular breastfeeding is considered the best source of nutrition that a mother can offer her newborn child [17-23]. Breastfeeding is a nutritive sucking habit that lowers the incidence of malocclusion in the primary dentition [19,24-27]. Some studies found that prolonged breastfeeding seems to lower the incidence of malocclusion [3], others did not find this association [19,28-32]. Furthermore, minimum duration of breastfeeding to effectively protect against malocclusion is currently under debate. In fact, some authors suggest that 6 months $[33,34]$ are enough while others recommend up to 12 months of breastfeeding. Several studies have investigated the connection between occlusion and breastfeeding and they often came to different conclusions. Some studies $[15,29]$ found no evidence of a connection between breastfeeding duration and malocclusion while others were able to define a precise relationship between reduced or no breastfeeding and the development of different kinds of malocclusion, i.e., skeletal class II [35], open bite [36] or posterior crossbite [37-39].

The aim of the present paper is to systematically review the present evidence on the relationship between breastfeeding and the development of malocclusion traits during childhood in primary and mixed dentition, taking into consideration whether the duration of breastfeeding is a relevant factor for the onset of the same.

\section{Materials and Methods}

The protocol was registered in the Prospective International Registration of Systematic Reviews (PROSPERO) database under the reference number CRD42019137471.The research refers to the Preferred Reporting Items for Systematic Reviews and Meta-Analyses (PRISMA-P) 2015 [40].

\subsection{Population, Intervention, Comparison, Outcome (PICO)}

The PICO model was designed as follows: Population-subjects with primary or mixed dentition; Exposure-breastfeeding duration, presence of non-nutritive sucking habits, use of pacifier; Comparison-absence of breastfeeding, duration of breastfeeding less than 6 months; Outcome- the prevalence of any malocclusion diagnosed through patients' objective examination, questionnaires or stone casts examination either in the transversal dimension (i.e., maxillary crowding or maxillary hypoplasia), in the vertical dimension(i.e., augmented or reduced anterior and/or posterior vertical dimension, skeletal and dental open or deep bite) and in the sagittal dimension that is skeletal and/or dental discrepancies between the mandible and maxilla (i.e., class 2 division 1 and division 2 according to Angle, primary canine distocclusion according to Foster and Hamilton, skeletal class 2 according to Steiner, augmented or reduced overjet, underdevelopment of the mandible)

\subsection{Search Strategy}

A rigorous electronic research was employed through the following electronic databases: Medline, Pubmed, Embase, Cochrane Library, Evidence-Based Medicine Reviews (EBMR), Web of Science and Ovid.

The following search strategy was conducted: (child* OR infant OR infant, newborn OR baby) AND ("breast feeding" (MeSH Terms) OR ("breast" (All Fields) AND "feeding” (All Fields)) OR "breast feeding" (All Fields) OR "breastfeeding" (All Fields)) AND ("malocclusion" (MeSH Terms) OR "malocclusion" (All Fields))) AND "humans" (MeSH Terms)). Hand searching in the references of included papers was performed to eventually retrieve any study that was not identified during the primary search. Two independent reviewers assessed the titles and abstracts of all the articles selected.

The EndNote software reference manager (Version X7× 9.21, Thomson Reuters, released September 2014, Toronto, ON, Canada) was adopted to archive and analyze retrieved references studies. 
The Kappa score [41] was chosen to evaluate agreement between the reviewers on the eligibility of retrieved results after reading the title and abstract. If the title and abstract was deemed insufficient to come to a decision, the full article was read to reach the final decision. A third researcher's opinion was requested in case of disagreement between the two reviewers.

\subsection{Inclusion and Exclusion Criteria}

Articles with proper description of the diagnostic method used, information about types of nutrition in neonates, use of nonnutritive sucking habits (i.e., use of pacifier, thumb sucking, tongue thrust, and finger sucking), duration of breastfeeding and diagnosis of malocclusion in the primary/mixed dentition were considered only. Moreover, no time limits in the search strategy were considered. The following article types were included: randomized controlled trials (RCTs), case-control studies and cohort studies. Papers that evaluated the present evidence on the connection between breastfeeding and malocclusion during childhood were included. Studies in a language other than English, animal studies, reviews, comments, conference abstracts, personal opinions, book chapters, letters to the editor, and studies with insufficient information about how the data were collected were excluded.

\subsection{Data Extraction}

The following data were gathered from each of the selected papers: journal and publication date, sample size, gender, study design, malocclusion diagnosis, information on breastfeeding and on the odds ratio (OR) between breastfeeding and malocclusion, instrument and time Interval of feeding habit evaluation and therapeutic outcomes.

\subsection{Quality Appraisal}

Newcastle-Ottawa Quality Assessment Scale (NOS) [42] for cohort and case-control studies was used for qualitative analysis of selected studies. The aforementioned quality appraisal tool is made of 8 points. Each paper can be rated with only one star for each point, besides Comparability that can be rated up to two stars. The maximum score is, therefore, nine stars. Quality assessment was performed independently by the same investigators that performed the literature search and study selection. In case of dispute, the third reviewer's opinion was asked.

\subsection{Limitations of the Review}

Because of the heterogeneity of study protocols, meta-analysis of the retrieved data was not possible. Therefore, only a qualitative analysis of retrieved studies was possible.

\section{Results}

The protocol registered with PROSPERO stated that this study would consider only papers published after the year 2000. Initially 279 articles were found in total. Two more papers from the gray literature were also included. The primary search retrieved 123 papers net of duplicates. Two papers were deemed excluded after reading the abstract, the title and the study design. Ninety three articles were excluded for mixed reasons (generation of random sequences; allocation concealment; blinding of participants and staff, blinding of the evaluation of results; incomplete outcome data; selective reporting; other prejudices.). Twenty eight papers were read in extenso, ten of them were excluded for lack of relevance. Eighteen articles were selected for qualitative analysis. Summary of clinical studies meeting inclusion criteria is shown in Table 1. The PRISMA flow chart (Figure 1) illustrates the search methodology and results. 
Table 1. Included studies characteristics.

\begin{tabular}{|c|c|c|c|c|c|c|c|c|c|}
\hline Author & $\begin{array}{l}\text { Publication } \\
\text { Date }\end{array}$ & Design & Journal & Sample Size & $\begin{array}{l}\text { Subjects'Age at the } \\
\text { Diagnosis of } \\
\text { Malocclusion }\end{array}$ & Orthodontic Diagnosis & $\begin{array}{l}\text { Malocclusion Types } \\
\text { Considered }\end{array}$ & Assessment Method & $\begin{array}{l}\text { Statistical } \\
\text { Analysis }\end{array}$ \\
\hline $\begin{array}{l}\text { Campos } \\
\text { MPMS et al. [14] }\end{array}$ & 2018 & $\begin{array}{l}\text { Cross-sectional } \\
\text { study }\end{array}$ & Braz Oral Res. & 290 & 6 years & $\begin{array}{c}\text { Clinical examination. } \\
\text { Anterior open bite was } \\
\text { diagnosed based on the } \\
\text { criteria given by Foster and } \\
\text { Hamilton [43]. }\end{array}$ & $\begin{array}{l}\text { Dental and skeletal } \\
\text { malocclusions were } \\
\text { evaluated. }\end{array}$ & $\begin{array}{l}\text { The Z-score development } \\
\text { index (ratio between } \\
\text { height and age) was } \\
\text { employed to express } \\
\text { nutritional status at birth } \\
\text { and at } 6 \text { years of age } \\
\text { (WHO reference } \\
\text { standard). }\end{array}$ & $\begin{array}{l}\text { Multivariate } \\
\text { logistic regression; } \\
\text { odds ratio }(\mathrm{OR}), \\
\text { chi-square test. }\end{array}$ \\
\hline $\begin{array}{l}\text { Costa } \\
\text { CTD. et al. [36] }\end{array}$ & & $\begin{array}{l}\text { Cross-sectional } \\
\text { study }\end{array}$ & Braz Oral Res. & 489 & $2-5$ years & WHO index & $\begin{array}{c}\text { Anterior crossbite, } \\
\text { open bite, median line } \\
\text { deviation, crowding or } \\
\text { spacing }\end{array}$ & Validated questionnaire. & $\begin{array}{c}\text { Bivariate and } \\
\text { multivariable } \\
\text { logistic regression, } \\
\text { odds ratio (OR) }\end{array}$ \\
\hline Germa et al. [44] & 2016 & Cohort study & Angle Orthod. & 422 & 3 years & $\begin{array}{l}\text { Clinical examination. } \\
\text { Direct inspection for } \\
\text { transverse and vertical } \\
\text { relation. }\end{array}$ & $\begin{array}{l}\text { Anterior open bite, } \\
\text { posterior crossbite. }\end{array}$ & $\begin{array}{l}\text { Self-administered } \\
\text { questionnaires }\end{array}$ & $\begin{array}{l}\text { Multiple logistic } \\
\text { regressions. }\end{array}$ \\
\hline $\begin{array}{l}\text { Lopes-Freire } \\
\text { GM et al. [15] }\end{array}$ & 2015 & $\begin{array}{l}\text { Cross-sectional } \\
\text { observational } \\
\text { survey }\end{array}$ & Prog Orthod. & 275 & $3-6$ years & $\begin{array}{l}\text { Clinical examination. Direct } \\
\text { inspection for transverse and } \\
\text { vertical relation. Angle } \\
\text { class/primary teeth canine } \\
\text { relationship for interarch } \\
\text { sagittal malocclusion. }\end{array}$ & $\begin{array}{c}\text { Posterior crossbite. } \\
\text { anterior open bite, } \\
\text { and overbite, sagittal } \\
\text { occlusal relationship } \\
\text { (angle class, primary } \\
\text { canine relationship, } \\
\text { overjet) }\end{array}$ & Validated questionnaire. & $\begin{array}{l}\text { Chi-square, } \\
\text { Fisher's exact } \\
\text { tests, odds ratio } \\
\text { (OR) }\end{array}$ \\
\hline $\begin{array}{l}\text { Peres } \\
\text { KG. et al. [39] }\end{array}$ & 2015 & Cohort study & Pediatrics & 1303 & 5 years & $\begin{array}{l}\text { Clinical examination in a } \\
\text { single home visit. } \\
\text { WHO classification }\end{array}$ & $\begin{array}{l}\text { Openbite; crossbite; } \\
\text { overjet. }\end{array}$ & $\begin{array}{l}\text { Questionnaire recorded } \\
\text { at } 3,12 \text {, and } 24 \text { months. }\end{array}$ & $\begin{array}{l}\text { Poisson } \\
\text { regression } \\
\text { analyses }\end{array}$ \\
\hline $\begin{array}{c}\text { Chen } \\
x \text { et al [38] }\end{array}$ & 2015 & $\begin{array}{l}\text { Cross- } \\
\text { sectional } \\
\text { study }\end{array}$ & BMC Pediatr. & 734 & $3-6$ years & Does not specify & $\begin{array}{l}\text { Deep bite, open bite, } \\
\text { anterior/posterior } \\
\text { crossbite, sagittal } \\
\text { relationship between } \\
\text { primary canines and } \\
\text { between second } \\
\text { primary molars, } \\
\text { presence or absence of } \\
\text { crowding or spacing. }\end{array}$ & $\begin{array}{l}\text { Questionnaire repeated } \\
\text { every six months for the } \\
\text { first three years of life } \\
\text { and the non-nutritive } \\
\text { sucking habits. }\end{array}$ & $\begin{array}{l}\text { Univariate } \\
\text { analysis and } \\
\text { multiple logistic } \\
\text { regressions }\end{array}$ \\
\hline
\end{tabular}


Table 1. Cont

\begin{tabular}{|c|c|c|c|c|c|c|c|c|c|}
\hline Author & $\begin{array}{l}\text { Publication } \\
\text { Date }\end{array}$ & Design & Journal & Sample Size & $\begin{array}{l}\text { Subjects'Age at the } \\
\text { Diagnosis of } \\
\text { Malocclusion }\end{array}$ & Orthodontic Diagnosis & $\begin{array}{l}\text { Malocclusion Types } \\
\text { Considered }\end{array}$ & Assessment Method & $\begin{array}{l}\text { Statistical } \\
\text { Analysis }\end{array}$ \\
\hline $\begin{array}{l}\text { Sum } \\
\text { FH et al. [18] }\end{array}$ & 2015 & $\begin{array}{l}\text { Cross-sectional } \\
\text { study }\end{array}$ & $\begin{array}{l}\text { BMC Oral } \\
\text { Health }\end{array}$ & 851 & $2-5$ years & $\begin{array}{c}\text { Own criteria } \\
\text { (Kappa 0.70-1.00) }\end{array}$ & $\begin{array}{l}\text { Incisal relationship; } \\
\text { sagittal relationship } \\
\text { between primary } \\
\text { canines and between } \\
\text { second primary molars, } \\
\text { overjet; } \\
\text { anterior/posterior } \\
\text { crossbite; anterior } \\
\text { openbite; overbite; } \\
\text { intercanine width; } \\
\text { intermolar width; } \\
\text { posterior crossbite }\end{array}$ & $\begin{array}{c}\text { Self-administered } \\
\text { questionnaires on feeding } \\
\text { habits and history of } \\
\text { non-nutritive sucking } \\
\text { habits }\end{array}$ & $\begin{array}{l}\text { Multinomial } \\
\text { logistic regression } \\
\text { models; } \\
\text { Multi-way } \\
\text { ANOVA. }\end{array}$ \\
\hline $\begin{array}{l}\text { Agarwal } \\
\text { SS et al. [45] }\end{array}$ & 2014 & $\begin{array}{l}\text { Cross-sectional } \\
\text { retrospective } \\
\text { study }\end{array}$ & Prog Orthod. & 415 & 4-6 years & $\begin{array}{l}\text { Self-defined criteria } \\
\text { statistically validated } \\
(\text { kappa }=0.758)\end{array}$ & $\begin{array}{l}\text { Anterior open bite, } \\
\text { posterior crossbite } \\
\text { upper and lower } \\
\text { inter-molar distance } \\
\text { (IMD) and inter-canine } \\
\text { distance (ICD) }\end{array}$ & $\begin{array}{l}\text { One-time administered } \\
\text { validated questionnaire }\end{array}$ & $\begin{array}{l}\text { Chi-square test } \\
\text { and Odds ratio to } \\
\text { assess the } \\
\text { strength of } \\
\text { correlations in } \\
\text { object. } \\
\text { Multivariate } \\
\text { logistic regression } \\
\text { to determine } \\
\text { independent } \\
\text { predictors of } \\
\text { posterior crossbite } \\
\text { and upper and } \\
\text { lower IMD and } \\
\text { ICD }\end{array}$ \\
\hline Limeira et al. [37] & 2014 & $\begin{array}{l}\text { Cross-sectional } \\
\text { retrospective } \\
\text { study }\end{array}$ & J Dent Child. & 714 & 6 to 9 years old & $\begin{array}{l}\text { The clinical examination was } \\
\text { performed with the subject } \\
\text { seated in a chair under } \\
\text { natural light, using } \\
\text { disposable tongue blades } \\
\text { and gloves. The occlusal } \\
\text { relationships were evaluated } \\
\text { in centric occlusion. }\end{array}$ & Posterior cross-bite & $\begin{array}{c}\text { A validated } \\
\text { questionnaire was } \\
\text { completed by guardians } \\
\text { concerning the length of } \\
\text { time they were } \\
\text { exclusively breast-fed } \\
\text { and the breast-feeding } \\
\text { duration. }\end{array}$ & Chi-square test. \\
\hline $\begin{array}{c}\text { Moimaz } \\
\text { SA et al. [46] }\end{array}$ & 2014 & $\begin{array}{l}\text { Prospective } \\
\text { cohort study }\end{array}$ & $\begin{array}{l}\text { BMC Oral } \\
\text { Health }\end{array}$ & 80 & 30th months of age & Not reported & $\begin{array}{l}\text { Overjet, Posterior } \\
\text { crossbite }\end{array}$ & $\begin{array}{l}\text { Self-administered } \\
\text { questionnaires at one } \\
\text { year, one and a half years } \\
\text { and two years of age }\end{array}$ & $\begin{array}{l}\text { Chi-squared and } \\
\text { Fisher's exact } \\
\text { tests }\end{array}$ \\
\hline
\end{tabular}


Table 1. Cont

\begin{tabular}{|c|c|c|c|c|c|c|c|c|c|}
\hline Author & $\begin{array}{l}\text { Publication } \\
\text { Date }\end{array}$ & Design & Journal & Sample Size & $\begin{array}{l}\text { Subjects'Age at the } \\
\text { Diagnosis of } \\
\text { Malocclusion }\end{array}$ & Orthodontic Diagnosis & $\begin{array}{l}\text { Malocclusion Types } \\
\text { Considered }\end{array}$ & Assessment Method & $\begin{array}{l}\text { Statistical } \\
\text { Analysis }\end{array}$ \\
\hline $\begin{array}{l}\text { Caramez da } \\
\text { Silva et al. [35] }\end{array}$ & 2012 & $\begin{array}{l}\text { Cross-sectional } \\
\text { study }\end{array}$ & Breastfeed Med. & 153 & 3 to 5 years old & $\begin{array}{l}\text { The sagittal relation between } \\
\text { the upper and lower jaw was } \\
\text { evaluated through direct } \\
\text { clinical examination } \\
\text { Distoclusion was diagnosed } \\
\text { according to Foster and } \\
\text { Hamilton's criteria [43] (the } \\
\text { cusp of the primary upper } \\
\text { canine occluded anterior to } \\
\text { the distal aspect of the } \\
\text { primary lower canine. }\end{array}$ & $\begin{array}{l}\text { Primary teeth sagittal } \\
\text { relationship }\end{array}$ & $\begin{array}{c}\text { Trained research } \\
\text { assistants gathered data } \\
\text { on dietary and } \\
\text { not-nutritive sucking } \\
\text { habits at } 7,30,60,120, \\
\text { and } 180 \text { days through a } \\
\text { telephonic or in person } \\
\text { interview (if the first } \\
\text { option was not viable) }\end{array}$ & $\begin{array}{l}\text { Poisson's } \\
\text { regression } \\
\text { analysis. }\end{array}$ \\
\hline Thomaz et al. [47] & 2012 & $\begin{array}{l}\text { Cross-sectional } \\
\text { study }\end{array}$ & $\begin{array}{l}\text { Int J Pediatr } \\
\text { otorhinolaryngol. }\end{array}$ & 2060 & $12-15$ years old & $\begin{array}{c}\text { Malocclusion and facial } \\
\text { characteristics were } \\
\text { evaluated as defined by } \\
\text { Angle }\end{array}$ & $\begin{array}{c}\text { Dental class as } \\
\text { described by Angle }\end{array}$ & Validated questionnaire. & $\begin{array}{c}\text { Odds ratio }(\mathrm{OR}) \\
\text { in multinomial } \\
\text { logistic regression } \\
\text { analysis }\end{array}$ \\
\hline $\begin{array}{c}\text { Jabbar } \\
\text { NS et al. [2] }\end{array}$ & 2011 & $\begin{array}{l}\text { Epidemiological } \\
\text { study, } \\
\text { cross-sectional } \\
\text { study }\end{array}$ & Braz Oral Res. & 911 & $3-6$ years & $\begin{array}{l}\text { Self-defined criteria } \\
\text { statistically validated } \\
\text { (Kappa: } 0.9 \text { to } 1.0 \text { ) }\end{array}$ & $\begin{array}{l}\text { Overjet (normally, } \\
\text { increased, anterior } \\
\text { crossbite). } \\
\text { Primary canine } \\
\text { relationships (Class } \\
1,2,3)\end{array}$ & $\begin{array}{l}\text { One-time validated } \\
\text { questionnaire. }\end{array}$ & $\begin{array}{c}\text { multiple binary } \\
\text { logistic regression } \\
(\alpha=0.05)\end{array}$ \\
\hline $\begin{array}{l}\text { Romero } \\
\text { CC et al. [3] }\end{array}$ & 2011 & $\begin{array}{l}\text { Cross-sectional } \\
\text { study }\end{array}$ & J Appl Oral Sci & 1377 & 3-6 years & $\begin{array}{l}\text { Clinical examinations were } \\
\text { performed by visual } \\
\text { inspection. }\end{array}$ & $\begin{array}{l}\text { Overbite alterations: } \\
\text { anterior open bite } \\
\text { (negative overbite) and } \\
\text { anterior deep bite } \\
\text { (increased overbite) }\end{array}$ & Validated questionnaire. & $\begin{array}{c}\text { Spearman's } \\
\text { correlation test., } \\
\text { chi-square tests } \\
\text { with odds ratio } \\
(\mathrm{OR}), \text { binary } \\
\text { logistic regression }\end{array}$ \\
\hline $\begin{array}{c}\text { Sanchez } \\
\text { Molins et al. [48] }\end{array}$ & 2010 & $\begin{array}{l}\text { Observational, } \\
\text { analytical and } \\
\text { retrospective } \\
\text { study }\end{array}$ & $\begin{array}{l}\text { Eur J Paediatr } \\
\text { Dent }\end{array}$ & 197 & 6-11years & $\begin{array}{l}\text { Cephalometric } \\
\text { measurements according to } \\
\text { Ricketts, Steiner and } \\
\text { McNamara. }\end{array}$ & $\begin{array}{c}\text { Dental, skeletal and } \\
\text { aesthetics variables } \\
\text { based on Ricketts, } \\
\text { Steiner and McNamara } \\
\text { values. }\end{array}$ & Validated questionnaire. & $\begin{array}{l}\mathrm{t} \text {-test and } \\
\text { ANOVA test, } \\
\text { chi-square test }\end{array}$ \\
\hline
\end{tabular}


Table 1. Cont.

\begin{tabular}{|c|c|c|c|c|c|c|c|c|c|}
\hline Author & $\begin{array}{l}\text { Publication } \\
\text { Date }\end{array}$ & Design & Journal & Sample Size & $\begin{array}{l}\text { Subjects'Age at the } \\
\text { Diagnosis of } \\
\text { Malocclusion }\end{array}$ & Orthodontic Diagnosis & $\begin{array}{l}\text { Malocclusion Types } \\
\text { Considered }\end{array}$ & Assessment Method & $\begin{array}{l}\text { Statistical } \\
\text { Analysis }\end{array}$ \\
\hline $\begin{array}{c}\text { Castelo } \\
\text { PM et al. [49] }\end{array}$ & 2010 & $\begin{array}{l}\text { Cross-sectional } \\
\text { study }\end{array}$ & J Appl Oral Sci. & 67 & 3.5 to 7 years & $\begin{array}{l}\text { Direct clinical examination of } \\
\text { allowed to gather the } \\
\text { following information: } \\
\text { anamneses, height and } \\
\text { weight, posterior crossbite, } \\
\text { distoclusion was diagnosed } \\
\text { according to Foster and } \\
\text { Hamilton's criteria [43] (the } \\
\text { cusp of the primary upper } \\
\text { canine occluded anterior to } \\
\text { the distal aspect of the } \\
\text { primary lower canine). }\end{array}$ & $\begin{array}{l}\text { Cross-bite, maximal } \\
\text { bite force. }\end{array}$ & $\begin{array}{l}\text { Direct clinical } \\
\text { examination and } \\
\text { interview of the } \\
\text { guardians about history } \\
\text { of breastfeeding, } \\
\text { presence and duration of } \\
\text { sucking habits. }\end{array}$ & $\begin{array}{c}\text { t-test, } \\
\text { Pearson's } \\
\text { correlation test } \\
\text { multiple logistic } \\
\text { regression } \\
\text { univariate } \\
\text { regression }\end{array}$ \\
\hline $\begin{array}{l}\text { Peres } \\
\text { KG et al. [33] }\end{array}$ & 2007 & $\begin{array}{l}\text { Cross-sectional } \\
\text { study }\end{array}$ & $\begin{array}{l}\text { Rev Saude } \\
\text { Publica. }\end{array}$ & 359 & Not reported & Direct clinical examination & $\begin{array}{l}\text { Anterior open bite and } \\
\text { posterior cross bite }\end{array}$ & $\begin{array}{l}\text { Repeated interview of the } \\
\text { guardians about } \\
\text { breastfeeding and } \\
\text { non-nutritive sucking } \\
\text { habits were performed at } \\
\text { birth, after } 3,6 \text { and } 12 \\
\text { months, and at six years } \\
\text { of age }\end{array}$ & $\begin{array}{l}\text { Chi-square test, } \\
\text { Poisson } \\
\text { regression test }\end{array}$ \\
\hline $\begin{array}{l}\text { Viggiano } \\
\text { D et al. [10] }\end{array}$ & 2004 & $\begin{array}{l}\text { Retrospective } \\
\text { study }\end{array}$ & $\begin{array}{l}\text { Arch Dis. } \\
\text { Child. }\end{array}$ & 1130 & $3-5$ years & $\begin{array}{l}\text { Direct clinical examination } \\
\text { by a pediatric dentist }\end{array}$ & $\begin{array}{l}\text { Altered sagittal } \\
\text { relationship; anterior } \\
\text { open bite; posterior } \\
\text { cross-bite }\end{array}$ & Structured ques-tionnaire & $\begin{array}{l}\text { Logistic } \\
\text { regression, } \\
\text { odds ratio }\end{array}$ \\
\hline
\end{tabular}

Significance threshold was set for all studies at $p<0.05$. 


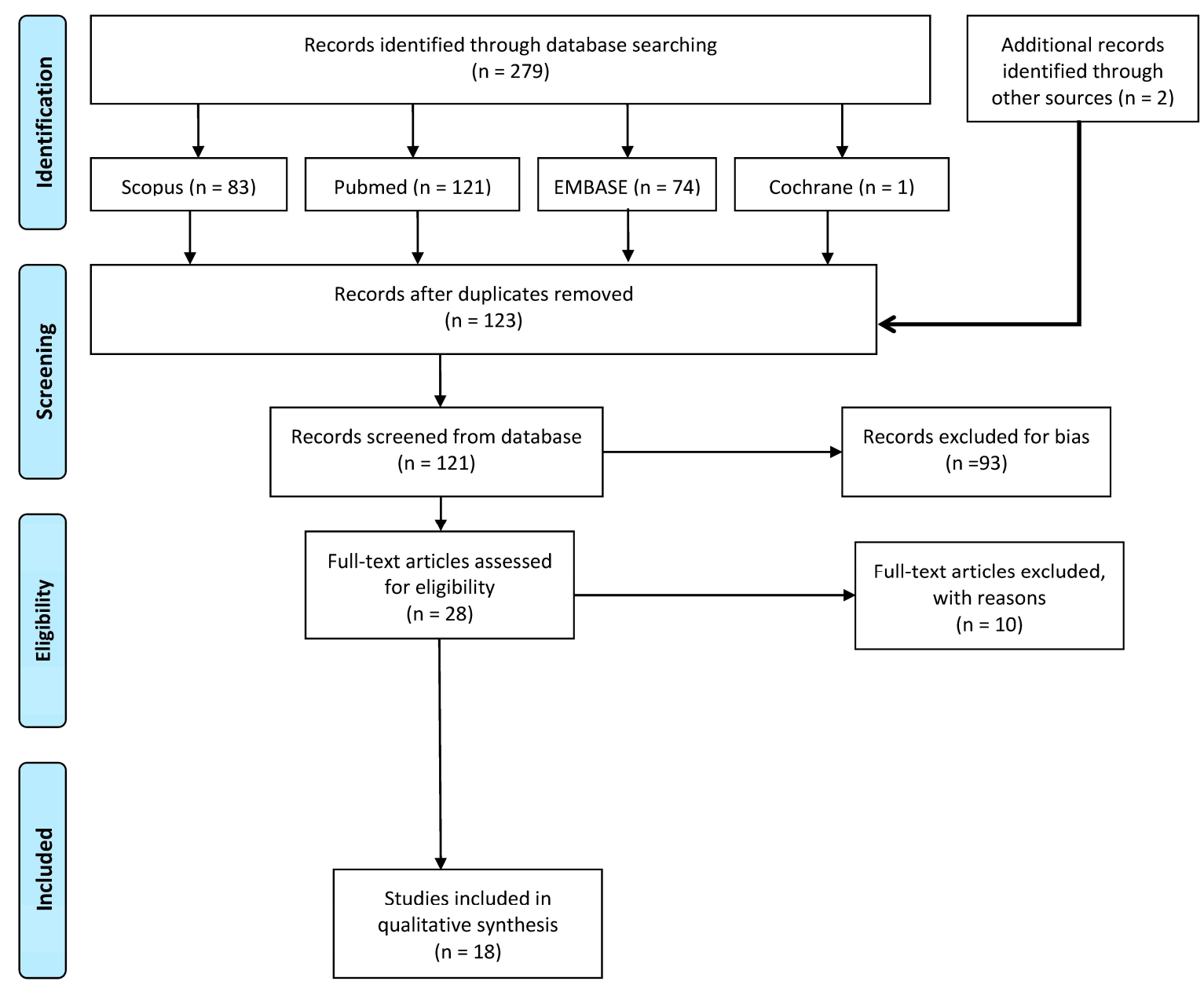

Figure 1. Preferred Reporting Items for Systematic Reviews and Meta-Analyses Protocols (PRISMA) flow chart.

\subsection{Description of the Included Studies}

Of the 18 papers selected, thirteen were cross-sectional, two cohort studies, two observational retrospective, one was a prospective study. The overall study sample was 11.827 children with a range between 80 and 2060 with an average age range of 3-5 years.

As regards to transverse skeletal malocclusion, 12 studies assessed the relationship between breastfeeding or bottle-feeding and maxillary hypoplasia (posterior crossbite). All of the studies, apart from Limeira et al. [37] and Sanchez Molins et al. [48] that assess the aforementioned association in mixed dentition, focused their attention on the primary dentition $[14,15,18,38,39,44,50]$.

As regards to vertical discrepancy, 12 studies $[3,10,14,15,18,34,36,38,39,44,45,48]$ investigated the relationship between breastfeeding and abnormal anterior overbite/openbite in deciduous teeth. Finally regarding sagittal discrepancy, seven studies $[2,15,18,36,38,39,48]$ evaluated the relationship between breastfeeding and anterior crossbite in deciduous teeth.

Thomaz et al. evaluated the relationship between breastfeeding and prevalence of class II in mixed dentition, Caramez da Silva et al. in deciduous teeth. The relationship between the development of occlusion in deciduous teeth and breastfeeding was assessed in three papers. 
The correlation between breastfeeding and the presence of diastemas in deciduous teeth was assessed in three papers [36,38,50]. Only one study [48] evaluated the relationship between maxillofacial growth pattern and breastfeeding in mixed dentition.

\subsection{Qualitative Synthesis}

All the eighteen observational studies scored moderate to high according to the NOS (Table 2).

Table 2. Quality scores of included studies according to Newcastle-Ottawa Quality Assessment Scale (NOS) for cohort studies.

\begin{tabular}{|c|c|c|c|c|c|c|c|c|c|c|}
\hline \multirow[t]{2}{*}{ Author (Year) } & \multicolumn{4}{|c|}{ Selection $(* * * *)$} & \multicolumn{2}{|c|}{ Comparability $(* *)$} & \multicolumn{3}{|c|}{ Outcome ${ }^{(* * *)}$} & \multirow[t]{2}{*}{ Total Score } \\
\hline & 1 & 2 & 3 & 4 & $5 \mathbf{a}$ & $5 b$ & 6 & 7 & 8 & \\
\hline Campos et al.(2018) [14] & * & * & & & & & * & * & & 4 \\
\hline Costa et al. (2018) [36] & & & & * & & & * & * & & 3 \\
\hline Germa et al.(2016) [44] & * & * & & & & & * & * & * & 5 \\
\hline Lopes-Freire et al. (2015) [15] & * & * & * & & & & * & * & & 5 \\
\hline Peres et al. (2015) [39] & * & * & * & & & & * & * & * & 6 \\
\hline Chen et al. (2015) [38] & * & * & & & & & * & * & & 4 \\
\hline Sum et al. (2015) [18] & * & * & & & & & * & * & & 4 \\
\hline Agarwal et al. (2014) [45] & * & * & & & & & * & * & & 4 \\
\hline Limeira et al. (2014) [37] & * & * & & * & & & * & * & * & 6 \\
\hline Moimaz et al. (2014) [46] & * & * & * & & & & * & * & * & 6 \\
\hline $\begin{array}{c}\text { Caramez da Silva et al. } \\
\text { (2012) [35] }\end{array}$ & * & * & & & & & * & * & * & 5 \\
\hline Thomaz et al. (2012) [47] & * & * & & & & & * & * & * & 5 \\
\hline Jabbar et al. (2011) [2] & * & * & & & & & * & * & * & 5 \\
\hline Romero et al.(2011) [3] & * & * & & & & & * & * & & 4 \\
\hline $\begin{array}{c}\text { Sanchez-Molins et al. } \\
\text { (2010) [48] }\end{array}$ & * & * & & & & & * & * & & 4 \\
\hline Castelo et al. (2010) [49] & * & * & * & & & & * & * & & 5 \\
\hline Peres et al. (2007) [33] & $*$ & * & * & & & & * & * & $*$ & 6 \\
\hline Viggiano et al. (2004) [10] & * & * & * & & & & * & * & & 5 \\
\hline
\end{tabular}

Description of NOS points: (1) Representativeness of the exposed cohort. (2) Selection of the non-exposed cohort.

(3) Ascertainment of exposure. (4) Demonstration that outcome of interest was not present at start of study.

(5) Comparability of cohorts on the basis of the design or analysis, (5a) for one factor and (5b) for additional factor.

(6) Assessment of outcome. (7) Duration of follow-up period. (8) Adequacy of follow-up.

Limeira et al. [37] observed that the absence or a reduced time of breastfeeding could be a risk factor for posterior crossbite in the mixed dentition. Likewise in the primary dentition, all of the studies apart from Germa et al. 2016 [44] found an increased risk for posterior crossbite and lower bite force if the baby was not breastfed or if it was breastfed for less than 6 months $[10,33,38,39,45,49]$.

As to vertical discrepancy conclusions vary through different studies. Peres et al. [39] and Romero et al. [3]. found that anterior open bite was associated with short time or no breastfeeding [33,44]. Moimaz et al. [46] found a greater prevalence of increased overbite in subjects that were breastfed for more than a year. Sum et al. [18], on the contrary, were unable to find any relationship between breastfeeding and vertical discrepancy

As to sagittal discrepancy, some studies found an association between longer breastfeeding and reduced overjet [18,39]. However, Moimaz et al. [46] reported increased overjet in subjects with more than a year of breastfeeding.

Some studies evaluated the association between dental class II and breastfeeding reported that subject breastfed for a longer time were less likely to develop this kind of malocclusion in primary dentition [35] and in mixed dentition [47].

As to occlusion development and breastfeeding, Peres et al. stated that breastfeeding promotes better occlusion [39], Campos et al. [14] reported that children that were not breastfed were more likely to develop malocclusion. On the contrary, Lopes-Freire et al. failed to find any connection between these two variables [15]. Costa et al. [36] stated that subjects that were never or not exclusively breastfed and used a pacifier had worse malocclusion than the ones exclusively breastfed and without not nutritive sucking habits. These authors assumed that the use of pacifier can modify the interaction between occlusal status and breastfeeding. 
Three papers $[36,38,50]$ evaluated the association between presence of diastemas in primary dentition and breastfeeding. Chen et al. [38] and Agarwall et al. [38] observed that breastfeeding for up to six months is associated to an absence of maxillary diastemas while Costa et al. associated breastfeeding to diastema and primate spaces [36].

Sanchez Molins et al. [48] evaluated the relationship between facial pattern and breastfeeding in mixed dentition and observed more brachyfacial pattern in subjects that have been breastfed.

\section{Discussion}

\subsection{Breastfeeding as a Prevention Factor for Development of Malocclusions}

It could be said that breastfeeding has a preventive effect on the development of malocclusions as it promotes adequate growth and bone and muscle development [39]. Breastfeeding reinforces the physiological nasal breathing of the newborn during and after sucking of breast milk, avoiding oral breathing and thus preventing the development of malocclusions [5,47]. The act of breastfeeding is positively associated with the development of dental arches in the temporal dentition in the anterior transverse and sagittal plane [18,51]. This fact is demonstrated in the study by Sánchez et al. where they compared lateral skull teleradiographs of 197 patients (106 breast-fed and 91 bottle-fed), using the cephalometric values of Ricketts, Steiner and McNamara and concluded that children who received breastfeeding had a correct relationship in the vertical and sagittal plane of the jaw with respect to the maxilla and the cranial base [43,52].

Lescano and Varela [51] examined a sample of 290 5-year-old children, divided into two groups: in group $\mathrm{A}$, children who received breastfeeding during the first months of life, and group B, those who only received artificial lactation. In conclusion, it was obtained that the highest percentage of children with normal occlusion were in group A, who received natural breastfeeding. In addition, it was observed that the cross bite was present in $1.9 \%$ of children fed with breast milk, and in a percentage greater than $16.9 \%$ in children fed by bottle feeding. Sum et al. conducted a cross-sectional study with a sample of 851 Asian children aged 2 to 5 years in the city of Hong Kong [18]. The parents of the children participating in the study completed a questionnaire to gather information on the use of breastfeeding and non-nutritive sucking habits.

Children breastfed for more than 6 months were less likely to develop a malocclusion in primary dentition, as they concluded that exclusive breastfeeding for more than 6 months is positively associated with the eugnathic development of the maxillomandibular complex both in the transversal and in the sagittal dimension that is children are less likely to develop maxillary hypoplasia and cross-bite and are less likely to develop a distoclusion in primary dentition (that is that the cusp tip of the maxillary primary canine tooth is mesial to the distal surface of the mandibular primary canine) [18]. Gomes et al. [52] carried out a study in Brazil with the objective of measuring and comparing the activity of masseter, temporal and buccal muscles in different forms of infant feeding. To do this, they took a sample of 60 children aged between 2 and 3 months, and distributed them into three groups: (1) Exclusive breastfeeding, (2) Breastfeeding supplemented with artificial feeding by bottle and (3) Breastfeeding supplemented with artificial feeding by cup. All children had a surface electromyography while feeding. With respect to the rate of movement and average contraction of the masseter and temporal muscles, greater activity was observed in the group fed through exclusive breastfeeding compared to the group fed with the bottle. In the case of bucinadores, differences were observed only in the range of contraction of these muscles, being more in the group fed by breastfeeding than in those fed by bottle.

These results suggest that there is similarity in the muscular activity of masseter, temporary and bucinadores in children fed exclusive breastfeeding and even supplemented with cup feeding; Therefore, the latter can be used as an alternative infant feeding method, improving its action on the bottle, due to the hyperactivity of the buccal muscles that could lead to changes in the structural growth and development of the stomatognathic system [53,54]. 


\subsection{Duration of Breastfeeding Related to the Appearance of Parafunctional Habits}

The scientific literature reports that for children fed by breastfeeding for a period equal to or greater than 6 months, this acts as a prevention factor for the acquisition of harmful oral habits, thanks to the psychological stability obtained by the intimate bond with the calming mother of that instinct of suction [4].

Thomaz et al. (2012), carried out a study in Brazil with a sample of 2060 students aged between 12 and 15, whose results showed the association between a short duration of breastfeeding (less than 6 months) and the development of malocclusions, highlighting Angle class II and a higher incidence of oral breathing in these patients. They concluded that breastfeeding by itself does not cause malocclusions but a synergistic effect can be observed in the presence of parafunctional habits in children who have been breastfed for less than 6 months [47].

In a study conducted by Lopes et al. (2015), the influence of breastfeeding on the development of non-nutritive sucking habits such as digital sucking and prolonged use of the pacifier was studied in a population of 275 children aged between 3 and 6, of the which 28 had received exclusive breastfeeding and 247 mixed breastfeeding. The presence of parafunctional habits was observed in 224 children $(81.5 \%)$. Among the results obtained, it should be noted that children who received exclusive breastfeeding did not have parafunctional habits [15]. Leite et al. (2007), conducted a study with the objective of relating the type of breastfeeding received with the development of non-nutritive sucking habits and malocclusions [53]. The sample consisted of 342 children aged between 3 and 5 years of age and observed that non-nutritive sucking habits had a high prevalence of 70 to $77.4 \%$ of the population studied. The malocclusions were present in $87 \%$ of the patients.

An proportion of $84.2 \%$ of the children reported having received breastfeeding and of these $79.9 \%$ presented some evidence of malocclusion at the time of the clinical examination. These authors conclude that there is a significant relationship between the period of breastfeeding, the continuation with artificial lactation and the appearance of non-nutritive sucking habits in children, and that this variable is strongly associated with the development of malocclusions. Of the 70 children who were fed by breastfeeding for a period equal to or greater than 19 months, $65.7 \%(n=46)$ had no deleterious oral habits [53]. Morales et al. [54], carried out a study in Caracas with the objective of evaluating the association between a short breastfeeding period of less than 6 months and the development of parafunctional habits analyzing 195 medical records of patients between the ages of 3 and 16 years old. The type of breastfeeding received, breastfeeding time, presence of harmful oral habits such as digital sucking, pacifier use, lingual interposition, bruxism, atypical swallowing and dyslalias and presence of malocclusions were investigated $[55,56]$. The authors observed that there was a direct relationship between breastfeeding time less than 6 months and development of parafunctional habits, the risk being greater for those children who did not receive breastfeeding [4].

\subsection{Bottle Feeding as an Etiological Factor and Promoter of Malocclusions and Harmful Oral Habits}

Artificial breastfeeding using a bottle, used as an alternative method to breastfeed, predisposes according to the scientific literature to the development of malocclusion.

Mendoza et al. 2008 [57], carried out a study with a sample of 500 Bolivian children aged between 3 and 7 years. The authors observed that breastfeeding during the first six months of life is represented as a prevention factor for the development of malocclusions. However, artificial feeding is represented as a risk factor for their development. It was observed that bottle-fed children had a $64 \%$ prevalence of non-nutritive sucking habits, the most frequent being digital suction with $53 \%$, followed by pacifier suction with $28 \%$ and other habits such as lingual interposition and lipstick in $19 \%$. They concluded that artificial feeding associated with non-nutritive sucking habits are the main risk factors that lead to the likelihood of developing malocclusions.

Moimaz et al. (2008), developed a study with a sample of 100 children under one year of age whose purpose was to evaluate the relationship on the type of feeding of infants and the development of non-nutritive sucking habits [46]. The results showed that $75 \%$ of the children were being fed 
through breastfeeding. The habits of digital sucking and sucking of the pacifier were obtained in $55 \%$ of the children, these habits being present in $74 \%$ of the children who were fed by bottle. These results suggest the hypothesis that artificial feeding can be considered a risk factor in the occurrence of non-nutritive sucking habits in children.

Chen et al. (2015), conducted a study with a sample of 734 children in Beijing where they observed how artificial breastfeeding time influences the development of malocclusions [38]. Children who were fed by the bottle for a period of time greater than 18 months have a risk greater than $1.6 \%, 1.16 \%$ and $1.43 \%$ of having, respectively, posterior cross bite, maxillary compression and canine Class II than children who received said feeding until 18 months.

In spite of being an efficient alternative of feeding in the infant, artificial lactation can give rise to an insufficient mandibular development due to a minimum functional requirement at the time of the feeding, since this last one is realized from a rigid material, inducing patterns of low muscle activity, causing transverse growth of the palate and inadequate dental alignment, situations that demonstrate a strong relationship with the presence of dental and skeletal malocclusions.

\section{Conclusions}

It appears a rather common finding in the literature that breastfeeding for 6 months or more reduces the risk for posterior crossbite and class II malocclusion in primary and mixed dentition. However, no clear evidence exists of breastfeeding being protective against other types of malocclusion (e.g., vertical discrepancy like open bite or deep bite). Prospective longitudinal studies with data on duration and on other characteristics of breastfeeding (e.g., exclusive or mixed breastfeeding, association with not nutritive sucking habits and so forth), and subsequent evaluation of the occlusal status during primary dentition, mixed dentition and permanent dentition would greatly help in reducing biases and confusing factors such as non-nutritional sucking habits.

Author Contributions: Conceptualization, C.M., A.A. and D.C.; methodology, A.A., A.F., and D.C.; validation, A.A., D.C. and A.F.; data curation, A.A., D.C., and A.F.; writing-original draft preparation, A.A., A.F., D.C.; writing-review and editing, A.A., D.C. and C.M.; supervision, G.F.; project administration A.A, D.C. and C.M.; All authors have read and agreed to the published version of the manuscript.

Funding: This research received no external funding.

Conflicts of Interest: The authors declare no conflict of interest.

\section{References}

1. Lieberman, D.E. Speculations about the selective basis for modern human craniofacial form. Evol. Anthr. Issues News Rev. 2008, 17, 55-68. [CrossRef]

2. Jabbar, N.S.A.; Bueno, A.B.M.; da Silva, P.E.; Scavone-Junior, H.; Inês Ferreira, R. Bottle feeding, increased overjet and Class 2 primary canine relationship: Is there any association? Braz. Oral Res. 2011, 25, 331-337. [CrossRef] [PubMed]

3. Romero, C.C.; Scavone-Junior, H.; Garib, D.G.; Cotrim-Ferreira, F.A.; Ferreira, R.I. Breastfeeding and non-nutritive sucking patterns related to the prevalence of anterior open bite in primary dentition. J. Appl. Oral Sci. 2011, 19, 161-168. [CrossRef] [PubMed]

4. Boronat-Catalá, M.; Montiel-Company, J.M.; Bellot-Arcís, C.; Almerich-Silla, J.M.; Catalá-Pizarro, M. Association between duration of breastfeeding and malocclusions in primary and mixed dentition: A systematic review and meta-analysis. Sci. Rep. 2017, 7, 5048. [CrossRef] [PubMed]

5. Peres, K.G.; Cascaes, A.M.; Nascimento, G.G.; Victora, C.G. Effect of breastfeeding on malocclusions: A systematic review and meta-analysis. Acta Paediatr. 2015, 104, 54-61. [CrossRef]

6. Anenden, H. 10 Facts on Breastfeeding. Available online: http://www.who.int/features/factfiles/breastfeeding/ en/index.html (accessed on 28 November 2020).

7. Maspero, C.; Fama, A.; Cavagnetto, D.; Abate, A.; Farronato, M. Treatment of dental dilacerations. J. Biol. Regul. Homeost. Agents 2019, 33, 1623-1627. 
8. Farronato, G.; Maspero, C.; Giannini, L.; Farronato, D. Occlusal splint guides for presurgical orthodontic treatment. J. Clin. Orthod. 2008, 42, 508-512.

9. da Silveira, L.M.; Prade, L.S.; Ruedell, A.M.; Haeffner, L.S.B.; Weinmann, A.R.M. Influence of breastfeeding on children's oral skills. Rev. Saude Publica 2013, 47, 37-43. [CrossRef]

10. Viggiano, D.; Fasano, D.; Monaco, G.; Strohmenger, L. Breast feeding, bottle feeding, and non-nutritive sucking; effects on occlusion in deciduous dentition. Arch. Dis. Child. 2004, 89, 1121-1123. [CrossRef]

11. Farronato, G.; Giannini, L.; Galbiati, G.; Maspero, C. Comparison of the dental and skeletal effects of two different rapid palatal expansion appliances for the correction of the maxillary asymmetric transverse discrepancies. Minerva Stomatol. 2012, 61, 45-55.

12. Maspero, C.; Giannini, L.; Riva, R.; Tavecchia, M.G.; Farronato, G. Nasal cycle evaluation in 10 young patients: Rhynomanometric analysis. Mondo Ortod. 2009, 34, 263-268. [CrossRef]

13. Farronato, G.; Giannini, L.; Galbiati, G.; Maspero, C. A 5-year longitudinal study of survival rate and periodontal parameter changes at sites of dilacerated maxillary central incisors. Prog. Orthod. 2014, 15, 3. [CrossRef] [PubMed]

14. de Morais Santos Campos, M.P.; de Melo Valença, P.A.; da Silva, G.M.; de Carvalho Lima, M.; Jamelli, S.R.; de Góes, P.S.A. Influence of head and linear growth on the development of malocclusion at six years of age: A cohort study. Braz. Oral Res. 2018, 32, e98. [CrossRef]

15. Lopes-Freire, G.M.; Cárdenas, A.B.C.; Suarez de Deza, J.E.E.; Ustrell-Torrent, J.M.; Oliveira, L.B.; Boj Quesada, J.R.J. Exploring the association between feeding habits, non-nutritive sucking habits, and malocclusions in the deciduous dentition. Prog. Orthod. 2015, 16, 43. [CrossRef] [PubMed]

16. Farronato, M.; Cavagnetto, D.; Abate, A.; Cressoni, P.; Fama, A.; Maspero, C. Assessment of condylar volume and ramus height in JIA patients with unilateral and bilateral TMJ involvement: Retrospective case-control study. Clin. Oral Investig. 2020, 24, 2635-2643. [CrossRef] [PubMed]

17. WHO Multicentre Growth Reference Study Group. Breastfeeding in the WHO Multicentre Growth Reference Study. Acta Paediatr. Suppl. 2006, 450, 16-26. [CrossRef]

18. Sum, F.H.K.M.H.; Zhang, L.; Ling, H.T.B.; Yeung, C.P.W.; Li, K.Y.; Wong, H.M.; Yang, Y. Association of breastfeeding and three-dimensional dental arch relationships in primary dentition. BMC Oral Health 2015, 15, 30. [CrossRef]

19. Aznar, T.; Galán, A.F.; Marín, I.; Domínguez, A. Dental arch diameters and relationships to oral habits. Angle Orthod. 2006, 76, 441-445. [CrossRef]

20. Kramer, M.S.; Kakuma, R. The optimal duration of exclusive breastfeeding: A systematic review. Adv. Exp. Med. Biol. 2004, 554, 63-77. [CrossRef]

21. Maspero, C.; Cavagnetto, D.; Abate, A.; Cressoni, P.; Farronato, M. Effects on the Facial Growth of Rapid Palatal Expansion in Growing Patients Affected by Juvenile Idiopathic Arthritis with Monolateral Involvement of the Temporomandibular Joints: A Case-Control Study on Posteroanterior and Lateral Cephalograms. J. Clin. Med. 2020, 9, 1159. [CrossRef]

22. Maspero, C.; Abate, A.; Bellincioni, F.; Cavagnetto, D.; Lanteri, V.; Costa, A.; Farronato, M. Comparison of a tridimensional cephalometric analysis performed on 3T-MRI compared with CBCT: A pilot study in adults. Prog. Orthod. 2019, 20, 40. [CrossRef] [PubMed]

23. Maspero, C.; Farronato, M.; Bellincioni, F.; Cavagnetto, D.; Abate, A. Assessing mandibular body changes in growing subjects: A comparison of CBCT and reconstructed lateral cephalogram measurements. Sci. Rep. 2020, in press. [CrossRef] [PubMed]

24. Vázquez-Nava, F.; Quezada-Castillo, J.A.; Oviedo-Treviño, S.; Saldivar-González, A.H.; Sánchez-Nuncio, H.R.; Beltrán-Guzmán, F.j; Vázquez-Rodríguez, E.M.; Vázquez Rodríguez, C.F. Association between allergic rhinitis, bottle feeding, non-nutritive sucking habits, and malocclusion in the primary dentition. Arch. Dis. Child. 2006, 91, 836-840. [CrossRef] [PubMed]

25. Lanteri, V.; Farronato, M.; Ugolini, A.; Cossellu, G.; Gaffuri, F.; Parisi, F.M.R.; Cavagnetto, D.; Abate, A.; Maspero, C. Volumetric Changes in the Upper Airways after Rapid and Slow Maxillary Expansion in Growing Patients: A Case-Control Study. Materials 2020, 13, 2239. [CrossRef] [PubMed]

26. Maspero, C.; Farronato, M.; Bellincioni, F.; Annibale, A.; Machetti, J.; Abate, A.; Cavagnetto, D. Three-Dimensional Evaluation of Maxillary Sinus Changes in Growing Subjects: A Retrospective Cross-Sectional Study. Materials 2020, 13, 1007. [CrossRef] 
27. Maspero, C.; Abate, A.; Cavagnetto, D.; Morsi, M.; Fama, A.; Farronato, M. Available Technologies, Applications and Benefits of Teleorthodontics. A Literature Review and Possible Applications during the COVID-19 Pandemic. J. Clin. Med. 2020, 9, 1891. [CrossRef]

28. Luz, C.L.F.; Garib, D.G.; Arouca, R. Association between breastfeeding duration and mandibular retrusion: A cross-sectional study of children in the mixed dentition. Am. J. Orthod. Dentofac. Orthop. Off. Publ. Am. Assoc. Orthod. Its Const. Soc. Am. Board Orthod. 2006, 130, 531-534. [CrossRef]

29. Warren, J.J.; Bishara, S.E. Duration of nutritive and nonnutritive sucking behaviors and their effects on the dental arches in the primary dentition. Am. J. Orthod. Dentofac. Orthop. Off. Publ. Am. Assoc. Orthod. Its Const. Soc. Am. Board Orthod. 2002, 121,347-356. [CrossRef]

30. Maspero, C.; Abate, A.; Cavagnetto, D.; Fama, A.; Stabilini, A.; Farronato, G.; Farronato, M. Operculectomy and spontaneous eruption of impacted second molars: A retrospective study. J. Biol. Regul. Homeost. Agents 2019, 33, 1909-1912. [CrossRef]

31. Abate, A.; Cavagnetto, D.; Fama, A.; Bellincioni, F.; Assandri, F. Efficacy of Operculectomy in the Treatment of 145 Cases with Unerupted Second Molars: A Retrospective Case-Control Study. Dent. J. 2020, 8, 65. [CrossRef]

32. Abate, A.; Cavagnetto, D.; Fama, A.; Matarese, M.; Lucarelli, D.; Assandri, F. Short term effects of rapid maxillary expansion on breathing function assessed with spirometry: A case-control study. Saudi Dent. J. 2020. [CrossRef]

33. Peres, K.G.; Barros, A.J.D.; Peres, M.A.; Victora, C.G. Effects of breastfeeding and sucking habits on malocclusion in a birth cohort study. Rev. Saude Publica 2007, 41, 343-350. [CrossRef] [PubMed]

34. Peres, K.G.; De Oliveira Latorre, M.D.R.D.; Sheiham, A.; Peres, M.A.; Victora, C.G.; Barros, F.C. Social and biological early life influences on the prevalence of open bite in Brazilian 6-year-olds. Int. J. Paediatr. Dent. 2007, 17, 41-49. [CrossRef] [PubMed]

35. Caramez da Silva, F.; Justo Giugliani, E.R.; Capsi Pires, S. Duration of breastfeeding and distoclusion in the deciduous dentition. Breastfeed. Med. Off. J. Acad. Breastfeed. Med. 2012, 7, 464-468. [CrossRef]

36. da Costa, C.T.; Shqair, A.Q.; Azevedo, M.S.; Goettems, M.L.; Bonow, M.L.M.; Romano, A.R. Pacifier use modifies the association between breastfeeding and malocclusion: A cross-sectional study. Braz. Oral Res. 2018, 32, e101. [CrossRef]

37. Limeira, A.B.; Aguiar, C.M.; de Lima Bezerra, N.S.; Câmara, A.C. Association between breast-feeding duration and posterior crossbites. J. Dent. Child. (Chic.) 2014, 81, 122-127.

38. Chen, X.; Xia, B.; Ge, L. Effects of breast-feeding duration, bottle-feeding duration and non-nutritive sucking habits on the occlusal characteristics of primary dentition. BMC Pediatr. 2015, 15, 46. [CrossRef]

39. Peres, K.G.; Cascaes, A.M.; Peres, M.A.; Demarco, F.F.; Santos, I.S.; Matijasevich, A.; Barros, A.J.D. Exclusive Breastfeeding and Risk of Dental Malocclusion. Pediatrics 2015, 136, e60-e67. [CrossRef]

40. Shamseer, L.; Moher, D.; Clarke, M.; Ghersi, D.; Liberati, A.; Petticrew, M.; Shekelle, P.; Stewart, L.A. Preferred reporting items for systematic review and meta-analysis protocols (PRISMA-P) 2015: Elaboration and explanation. BMJ 2015, 350, g7647. [CrossRef]

41. Landis, J.R.; Koch, G.G. The Measurement of Observer Agreement for Categorical Data. Biometrics 1977, 33, 159-174. [CrossRef]

42. Wells, G.; Shea, B.; O'Connell, D.; Peterson, J.; Welch, V.; Losos, M.; Tugwell, P. The Newcastle-Ottawa Scale (NOS) for Assessing the Quality of Nonrandomised Studies in Meta-Analyses. Available online: http://www.ohri.ca/programs/clinical_epidemiology/oxford.asp (accessed on 28 November 2020).

43. Foster, T.D.; Hamilton, M.C. Occlusion in the primary dentition. Study of children at 2 and one-half to 3 years of age. Br. Dent. J. 1969, 126, 76-79. [PubMed]

44. Germa, A.; Clément, C.; Weissenbach, M.; Heude, B.; Forhan, A.; Martin-Marchand, L.; Bonet, M.; Vital, S.; Kaminski, M.; Nabet, C. Early risk factors for posterior crossbite and anterior open bite in the primary dentition. Angle Orthod. 2016, 86, 832-838. [CrossRef] [PubMed]

45. Agarwal, S.S.; Sharma, M.; Nehra, K.; Jayan, B.; Poonia, A.; Bhattal, H. Validation of Association between Breastfeeding Duration, Facial Profile, Occlusion, and Spacing: A Cross-sectional Study. Int. J. Clin. Pediatr. Dent. 2016, 9, 162-166. [CrossRef]

46. Moimaz, S.A.S.; Garbin, A.J.Í.; Lima, A.M.C.; Lolli, L.F.; Saliba, O.; Garbin, C.A.S. Longitudinal study of habits leading to malocclusion development in childhood. BMC Oral Health 2014, 14, 96. [CrossRef]

47. Thomaz, E.B.A.F.; Cangussu, M.C.T.; Assis, A.M.O. Maternal breastfeeding, parafunctional oral habits and malocclusion in adolescents: A multivariate analysis. Int. J. Pediatr. Otorhinolaryngol. 2012, 76, 500-506. [CrossRef] 
48. Sánchez-Molins, M.; Grau Carbó, J.; Lischeid Gaig, C.; Ustrell Torrent, J.M. Comparative study of the craniofacial growth depending on the type of lactation received. Eur. J. Paediatr. Dent. 2010, 11, 87-92. [PubMed]

49. Castelo, P.M.; Gavião, M.B.D.; Pereira, L.J.; Bonjardim, L.R. Maximal bite force, facial morphology and sucking habits in young children with functional posterior crossbite. J. Appl. Oral Sci. 2010, 18, 143-148. [CrossRef]

50. Agarwal, S.S.; Nehra, K.; Sharma, M.; Jayan, B.; Poonia, A.; Bhattal, H. Association between breastfeeding duration, non-nutritive sucking habits and dental arch dimensions in deciduous dentition: A cross-sectional study. Prog. Orthod. 2014, 15, 59. [CrossRef]

51. Lescano de Ferrer, A.; Varela de Villalba, T.B. Effect of the suction-swallowing action on orofacial development and growth. Rev. Fac. Cien. Med. Univ. Nac. Cordoba. 2006, 63, 33-37.

52. Gomes, C.F.; Trezza, E.M.C.; Murade, E.C.M.; Padovani, C.R. Surface electromyography of facial muscles during natural and artificial feeding of infants. J. Pediatr. (Rio J.) 2006, 82, 103-109. [CrossRef]

53. Leite-Cavalcanti, A.; Medeiros-Bezerra, P.K.; Moura, C. Breast-feeding, bottle-feeding, sucking habits and malocclusion in Brazilian preschool children. Rev. Salud Publica (Bogota) 2007, 9, 194-204. [CrossRef] [PubMed]

54. Morales-Chávez, M. Influencia de la lactancia materna en la aparición de hábitos parafuncionales y maloclusiones. Estudio transversal Influence of Breastfeeding on the Development of Parafunctional Habits and Malocclusions. A Cross-sectional Study. Univ. Odontol. 2014, 33. [CrossRef]

55. Maspero, C.; Prevedello, C.; Giannini, L.; Galbiati, G.; Farronato, G. Atypical swallowing: A review. Minerva Stomatol. 2014, 63, 217-227. [PubMed]

56. Farronato, G.; Giannini, L.; Riva, R.; Galbiati, G.; Maspero, C. Correlations between malocclusions and dyslalias. Eur. J. Paediatr. Dent. 2012, 13, 13-18. [PubMed]

57. Mendoza, A.; Asbún, P.; Crespo, A.A.; Gonzales, S.; Patiño, R. Relation between maternal breast feeding and habits of non nutritive suction with dental altered occlusion. Rev. Soc. Bol. Ped. 2008, 47, 3-7.

Publisher's Note: MDPI stays neutral with regard to jurisdictional claims in published maps and institutional affiliations.

(C) 2020 by the authors. Licensee MDPI, Basel, Switzerland. This article is an open access article distributed under the terms and conditions of the Creative Commons Attribution (CC BY) license (http://creativecommons.org/licenses/by/4.0/). 